\title{
Türkiye'de okul öncesinde kaynaştırma eğitimine ilişkin paydaş görüşlerinin incelenmesi: Bir derleme çalışması
}

\section{The investigation of stakeholders' opinions about inclusive education in early childhood in Turkey: A literature review}

\author{
Elif Buldu ${ }^{1}$, Aslıhan Özer², Gülşah Çalışkan ${ }^{3}$
}

\section{Makale Geçmişi \\ Geliş : : 1 Ocak 2021 \\ Düzeltme : 19 Mayis 2021}

Kabul : 21 Haziran 2021

\section{Makale Türü}

Derleme Makale

\section{Article History}

Received : 1 January 2021

Revised : 19 May 2021

Accepted : 21 June 2021

\section{Article Type}

Review Article
Öz: Bu çalışmanın amacı, okul öncesi dönemde uygulanan kaynaștırma eğitimine yönelik paydaşlarla yapılan ve 2000-2019 yılları arasında Türkiye'de gerçekleştirilen çalışmaları incelemek ve ülkemizdeki mevcut durumu değerlendirmektir. Ele alınan paydaşlar; öğretmen ve öğretmen adayları, anne-baba ve kaynaştırma eğitimine dahil edilen çocuklardan oluşmaktadır ve onların görüşlerinin tematik dağılımları incelenmiştir. Araştırma kapsamında, ULAKBİM ve Yüksek Öğretim Kurumu'de taranan araştırma ve derleme makaleleri, yüksek lisans ve doktora tez çalışmalarından oluşan toplam 36 yayına ulaşılmıştır. Yapılan araştırma sonucunda kaynaştırma eğitiminin paydaşlarla yapılan araştırmalar kapsamında, kaynaştırmaya karşı sergilenen tutum, bilgi düzeyi, bakış açısı, yaşanılan zorluklar, kaygı düzeyleri ve sosyal uyum gibi çeşitli değişkenler incelenmiştir. Araştırma bulguları, öğretmenlerin kaynaştırma eğitiminde kendilerini eksik ve yetersiz hissettiklerini göstermiştir. Ailelerin, kaynaştırma eğitimine geçiş sürecinde yeterince bilgi sunulmadığı için zorlandıkları görülmüştür. Ayrıca diğer paydaş olan çocukların, kaynaştırma eğitimi sürecinde genellikle akranları ile iletişimde sorunlar yaşadıkları bulunmuştur.

Anahtar Kelimeler: Okul öncesi eğitim, Kaynaştırma eğitimi, Paydaşlar, Paydaş görüşleri

Abstract: The aim of this study is to examine the studies carried out with stakeholders for inclusive education applied in the preschool period in Turkey between 2000-2019 and to evaluate the current situation in our country. As Stakeholders, it consists of in-service and pre-service teachers, parents, and children included in the inclusive education, and the thematic distribution of their views have been examined. Within the scope of the research, a total of 36 publications consisting of research and review articles, master and doctoral thesis studies scanned in the ULAKBIM and The Council of Higher Education (CHE) Documentation Department were reached. As a result of the research, the studies conducted with the stakeholders of inclusive education, the attitude towards inclusive, knowledge level, perspective, difficulties experienced, anxiety levels, and social adaptation variables were examined. The findings of the current study showed that teachers feel themselves incomplete and inadequate in inclusive education. It was observed that families had difficulties due to insufficient information provided during the transition to inclusive education. In addition, it was found that children, who are other stakeholders, often have problems in communication with their peers during the inclusive education process.

Keywords: Pre-school education, Inclusive education, Stakeholders, Stakeholders' views 


\section{SUMMARY}

\section{Introduction}

Today, educational models are moving away from the understanding of creating a "one-size-fits-all pattern" to respond to the individual differences and needs of students. This understanding has spread all over the world in a short time (OECD, 1995). Considering developmental characteristics, early childhood years are accepted as the period in which inclusive education is most beneficial for children with special needs (Orhan, 2010). It is seen that children with special needs make significant progress in their developmental areas (such as physical, cognitive, social, emotional development) (Lessard, 2015). Important improvements such as adaptation to the social environment and social events and gaining autonomy can be achieved through inclusive education (Hornby, 2014). Unfortunately, some studies show that children with special needs are isolated from children of their age, despite being educated in general education classes. On the other hand, many studies have shown that this is wrong and that children with special needs benefit from a learning environment where they interact with their peers (Graham \& Perrin, 2007). When the researches on inclusive education are examined, it is possible to find many studies in this field. In addition, Sönmez and Bıçak (2017) applied a scale to pre-school teachers to investigate their self-efficacy perception levels.

\section{Method}

The current study aimed to examine the studies conducted with different stakeholders for the implementation of inclusive education in early childhood in Turkey. The studies examined in Turkey because it is important to examine the distribution of thematic stakeholders' opinions regarding inclusive education in early childhood education in a descriptive nature (Büyüköztürk, Kılıç Çakmak, Akgün, Karadeniz ve Demirel, 2017). In the present study, studies conducted with teachers and teacher candidates, parents, school staff- administrators, and children included in inclusive education between 2000-2019 were included. In this study, which was conducted as a review of related research, a total of 36 publications published within the scope of research and review articles, master's and doctoral thesis were reached. The research articles obtained for this study were accessed from the ULAKBIM database, and the thesis and articles were obtained from YÖK Documentation Department. After reaching the aforementioned studies, the findings obtained as a result of the research were expressed in tables by dividing them into years and themes. The determined time interval for the studies obtained is between 2000-2019. A time interval of approximately 20 years has been determined for the studies to be handled in screening. This time choosing which researchers followed the history of inclusive education in Turkey and have begun to be applied considering the time elapsed. In the sample of the study, attention was paid to have a homogeneous distribution reflecting the selected time interval.

\section{Findings}

The findings of the studies obtained from; (1) studies on the opinions of teachers and teacher candidates on inclusive in the early childhood period, (2) studies on parents' views on inclusive in the early childhood

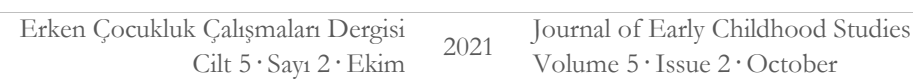


period, (3) studies on children's views on inclusive in the early childhood period are presented under 4 main headings. A total of 21 studies have been reached, which conducted with teachers and teacher candidates on inclusive education in the early childhood period to address their views. To investigate parents' views, a total of 10 studies were obtained, which were conducted with parents on inclusive education in the early childhood period. For studies with children, a total of 5 studies were conducted with children on inclusive education in the early childhood period. Information such as the year of study, author, the title of the study, research method were presented systematically in the tables.

\section{Discussion and Conclusion}

As a result of the reviewing of studies conducted with teachers in the present study, it was revealed that teachers who were children of inclusive in their class felt themselves inadequate and inadequate to inclusive education. Although most of them have received special education or inclusive education in undergraduate education, these courses are not enough for them. They expressed that they need to be supported through in-service training, conferences, and seminars. The parents are an integral part of inclusive education because the successful execution of this process is achieved with their participation and the need for them cannot be ignored (Lessard, 2015). Therefore, the difficulties experienced by parents have children with special needs such as; school selection, difficulties in the social adaptation of the child, teacher choice, anxiety about not being accepted by the other peers of the child. Parents state that they have difficulties because they do not provide enough information about the transition phase of their children to inclusive education after early childhood. For this reason, many of them worry about their children's adaptation to school and acceptance by their peers. In studies conducted with children, who are the most important stakeholders of inclusive education, Çulhaoğlu-İmrak and Sığırtmaç (2009) observed that typically developing children included their friends with special needs in their games and classroom environment. However, in the study conducted by Güleryüz (2009), children with special needs were exposed to violence and exclusion because they were perceived as deficient and inadequate by their typically developing friends. As a result, in addition to social perception, teachers may behave negatively towards inclusive education and children with special needs due to their lack of knowledge (Lessard, 2015). Similarly, teachers' negative attitudes towards inclusive education practices, their lack of belief, and their thinking that general education classes will not be sufficient for children with special needs and that they will not contribute to children are shown as one of the obstacles to the success of inclusive practices (Küçük-Doğaroğlu \& Bapoğlu-Dümenci, 2015). For this reason, it would be beneficial to integrate the special education lessons given in the teacher training programs of universities with the real school experience. 


\section{GİRİŞ}

Günümüzde eğitim modelleri, öğrencilerin bireysel farklılıklarına ve ihtiyaçlarına yanıt vermek için "bir beden herkese uyar" anlayışından uzaklaşmaktadır. Bu anlayış çerçevesinde, 1970’li yıllarda, Amerika Birleşik Devletleri’nde özel gereksinimli öğrenciler için başlatılan “kaynaştırma uygulamalar" kısa zamanda tüm dünyaya yayılmış, İtalya, İngiltere ve Fransa gibi ülkelerde özel eğitim yasalarıyla hayata geçirilmiştir (OECD, 1995). Kaynaştırma eğitimi sayesinde tüm çocuklar eğitim imkanlarına eşit erişime sahip konuma getirilmeye çalışılmaktadır. İnsan hakları evrensel bildirgesi, tüm çocukların okula devam etmesini ve akranlarıyla birlikte eğitim almalarının doğal hakları olduğunu savunmaktadır. Diğer taraftan, özel gereksinimi olan ve tipik gelişim gösteren çocuklar için kendilerini ait hissettikleri bir eğitim ortamı yaratmak kaliteli eğitimin temel amaçlarından biri olarak kabul edilmektedir (United Nations International Children's Emergency, 2004). Her çocuğa eşit imkan sunan bir öğrenme ortamı yaratmak için kaynaştırma eğitimi önemlidir çünkü kaynaştırma eğitimi toplumda içinde birey olmaya, özgürlüğü desteklemeye ve ayrımcılık yapmamaya teşvik etmede yardımcı olmaktadır (Berry, 2006). Dolayısıyla kaynaştırma eğitimi, öğrenme çeşitliliğini destekleyen ve engelleri kaldıran bir eğitim anlayışı olarak görülmektedir (Lessard, 2015). Kaynaştırma eğitimin uluslararası olarak kabul edilmiş bir tanımı olmamasına rağmen, Avrupa Ajansı (2015) her yaştaki tüm çocuklara yaşıtlarıyla birlikte yüksek kaliteli ve anlamlı eğitim verilmesi gerektiğini belirtmektedir. Bu tanımla birlikte, kaynaştırma eğitiminin çocuk merkezli öğrenme yaklaşımı etrafinda şekillendiği bir başka önemli nokta daha vardır. Bu da, çocukların yetersizliklerinden veya bireysel zayıflıklarından ziyade çocukların sıkıntılarına odaklanan bir eğitim ortamı olması gerektiği anlayışına inanmaktır (Booth ve Ainscow, 2002). Kaynaştırma eğitimi konusunda pek çok eğitim modeli sunulmaktadır ancak bu modellerin ortak noktaları; özel gereksinimi olan çocukların genel eğitim ortamında eğitim görmesidir (Jacobs ve Fu, 2014). Kaynaştırma eğitimi, tipik gelişim gösteren çocukları ve özel gereksinimli çocukları yetenekleri dikkate alınarak ayırmak değil, birlikte aynı ortamda bulunmalarını sağlamakta ve çocukların birbirlerinin ihtiyaçlarının farkına varabilmelerini sağlamaktadır. Bireylerin her biri kendine özgü fiziksel özelliklere, öğrenme hızına ve kapasitesine, duyuşsal ve duygusal özelliklere sahiptirler (Sönmez ve Bıçak, 2017; İlgar, 2017).

Özel gereksinimli çocukların gelişim özellikleri göz önüne alındığında okul öncesi dönemde kaynaştırma eğitiminin, onlar için en fazla yarar sağlandığı dönem olarak kabul edilmektedir (Orhan, 2010). Kaynaştırma uygulamaları başarılı bir şekilde uygulamaya yansıtıldığında, özel gereksinimli çocukların gelişim alanlarında (fiziksel, bilişsel, sosyal, duygusal gelişim gibi) önemli ölçülerde ilerleme kaydettikleri görülmektedir (Lessard, 2015). Kaynaştırma eğitimi sayesinde çocukların 
sosyal çevreye ve toplumsal olaylara uyum sağlayabilme, özerklik kazanma gibi önemli kazanımlar elde ettikleri de gösterilmiştir (Hornby, 2014). Diğer taraftan, özel gereksinimli çocuklarla birlikte öğrenim gören tipik gelişim gösteren bir çocuk, özel gereksinimli bireyleri tanımakta, diğer insanlara karşı duyarlı olmakta, farklılıklara sayg1 duymayı öğrenmekte ve onlara karşı olan olumsuz tutumlarını değiştirmektedir (Alper ve Ryndak, 1992). Özel gereksinimli çocukların eğitiminde büyük önem taşıyan kaynaştırma eğitimi çalışmaları ülkemizde 1983 yllında yasal olarak kabul edilmiş ve 1986 yılından özel gereksinimli çocukların eğitim kurumlarına yerleştirilmesi ile başlamıştır (Yazıcı̆̆lu, 2018). Şuan ülkemizdeki kaynaştırma eğitimi uygulamaları, örgün eğitim kurumlarında özel gereksinimli çocukların tipik gelişim gösteren çocuklar ile birlikte eğitim ve öğretime devam ettikleri özel eğitim uygulamalarındandır (MEB, 2018).

Ne yazık ki yapılan bazı araştırmalar, özel gereksinimli çocukların genel eğitim görmelerine rağmen kendi yaşıtındaki çocuklardan izole edildiklerini göstermektedir (Hornby, 2014; Lessard, 2015). Diğer taraftan, pek çok çalışma özel gereksinimli çocukları, tipik gelişim gösteren çocuklardan ayrı eğitmenin yanlış olduğunu ve özel gereksinimli çocukların yaşıtlarılla etkileşime girdikleri bir öğrenme ortamında fayda gördüklerini göstermiştir (Graham ve Perrin, 2007). Kaynaştırma eğitimi kapsamında farklı paydaşlarla (öğretmen ve öğretmen adayları, anne-babalar ve kaynaştırma eğitimine dahil edilen çocuklarla) yapılan araştırmalar incelendiğinde, bu alanda yapılmış çok sayıda çalışma bulmak mümkündür. Bunlardan biri İlgar (2017) tarafından 26 öğretmen adayı ile gerçekleştirilmiştir. Araştırmanın bulguları, öğretmen adaylarının çoğunun bu çocuklarla nasıl iletişim kuracaklarını bilmediğini göstermiştir. Bazı çalışmalar ise, öğretmenlerin ve ebeveynlerin özel gereksinimleri olan çocukların, diğer çocuklardan izole edilmelerinden şikayetçi olduklarını göstermiştir çünkü bu uygulamaların çocukların akranlarıyla olan etkileşimini sınırlandırdığını ifade etmişlerdir (Graham ve Perrin, 2007). Aydoğan ve arkadaşları (2016), öğretmenlerin çoğunun özel gereksinimi olan çocukları tanımakta güçlük çektiğini ve fark ederlerse onları tanımada herhangi bir çaba göstermediklerini ifade etmektedir. Diğer bir paydaş olan, ailelerle yürütülen çalısmalar kapsamında Ersoy Quadır ve Temiz (2018) tarafından gerçekleştirilen çalışmada, özel gereksinimli çocuğu olan annelerin gereksinimleri eğitim düzeyleriyle, gelirleriyle, çocuk sayısıyla ve devletten aldıkları maddi destek ile ilişkili bulunmuştur.

Özel eğitime gereksinim duyan çocukların bireysel ihtiyaçlarına göre erken teşhisi, etkili öğrenme firsatları sağlamak açısından oldukça önemlidir (Doğan, Gürgür, Girgin, Karasu, ve Turan, 2016). Bu sayede öğretmenler, kaynaştırma yoluyla özel ihtiyaçları olan çocukların ihtiyaçlarını karşılayacak öğrenme sürecini ve ortamını düzenleyebilirler (Çulhaoğlu-İmrak ve Sığırtmaç, 2009). Diğer taraftan, özel eğitimi uygulayabilecek fiziksel olarak uygun bir öğrenme ortamı sunmak, özel 
gereksinimli ve tipik gelişim gösteren çocukların bireysel özelliklerini dikkate alarak bireyselleştirilmiş eğitim programı hazırlamak gerekmektedir (Eripek, 2003). Tüm bu bilgiler göz önüne alındığında, alınan eğitimden dolaylı yada doğrudan hem etkilenen hem de etkileyen grupları düşündüğümüzde, okul öncesi eğitimindeki paydaşların (öğretmenlerinin, öğretmen adaylarının ve ailelerin) bilgi ve farkındalıklarının artırılması, kaynaştırma eğitimi için oldukça önemli bir yere sahiptir. Bu bağlamda yapılan çalısmaya ait araştırma sorusu; Türkiye'de 2000-2019 yılları arasında, okul öncesi dönemde kaynaştırma eğitimi hakkında paydaşların görüşlerine ilişkin yapılan çalışmalara ait bulgular nelerdir?

\section{YÖNTEM}

Bu çalışmanın amac1, Türkiye'de okul öncesi dönemde uygulanan kaynaştırma eğitimine yönelik farklı paydaşlarla yapılan çalışmalanı incelemektir. Yapılan çalışma, Türkiye'de okul öncesinde kaynaştırma eğitimine ilişkin paydaş görüşlerinin tematik dağılımlarını ele aldığından dolayı betimsel bir araştırma niteliğinde olup, alanyazın tarama modeli tipinde bir araştırmadır (Büyüköztürk vd., 2009). Mevcut çalışmada, 2000-2019 y1lları arasında okul öncesinde kaynaştırma eğitiminin paydaşlarını oluşturan; öğretmen, anne-baba ve kaynaştırma eğitimine dahil edilen çocuklarla ilgili yapılan araştırmalar dahil edilmiştir. İlgili araştırmaların taraması niteliğinde gerçekleştirilen bu çalışmada; araştırma ve derleme makaleler, yüksek lisans ve doktora tez çalışmaları kapsamında yayınlanmış toplam 36 yayına ulaşılmıştır.

Elde edilen derleme ve araştırma makalelerine; ULAKBİM veri tabanından ulaşılmış, tez ve makaleler ise YÖK Dokümantasyon Dairesi Başkanlığg'ndan temin edilmiştir. Bu alanda yürütülen çalışmalara ulaşıldıktan sonra (Temel, 2000; Sargın ve Sünbül, 2002; Varlıer ve Vuran, 2002; Odluyurt, 2007; Altun ve Gülben, 2009), y1llara ve temalara ayrllarak araştırma sonucunda elde edilen bulgular tablolarla ifade edilmiştir. Elde edilen çalışmalara ait belirlenen zaman aralığı 20002019 yılları arasındadır. Taramada ele alınacak çalışmalar için yaklaşık 20 yıllık bir zaman aralığ1 belirlenmiştir. Bu süreyi seçerken araştırmacılar, Türkiye'deki kaynaştırma eğitiminin geçmişini ve uygulanmaya başlanmasının ardından geçen süreyi göz önünde bulundurmuşlardır. Çalışmanın örnekleminde, seçilen zaman aralı̆̆ını yansıtan homojen bir dağılım olmasına dikkat edilmiştir. Tablo 1'de ilgili çalışmalara ait yayın aralığı, veri tabanı, yayın türleri ve anahtar kelimelere ait bilgiler sunulmuştur.

Tablo 1. Taramada seçilen kaynaklara ait bilgiler

\begin{tabular}{|c|c|c|}
\hline $\begin{array}{l}\text { Yayın tarihine ait zaman } \\
\text { aralığı }\end{array}$ & $2000-2019$ & \\
\hline Fin & $\begin{array}{l}\text { cukluk Çalışmaları Dergisi } \\
\text { Cilt } 5 \cdot \text { Sayı } 2 \cdot \text { Ekim }\end{array}$ & $\begin{array}{l}\text { Journal of Early Childhood Studies } \\
\text { Volume } 5 \cdot \text { Issue } 2 \cdot \text { October }\end{array}$ \\
\hline
\end{tabular}




\begin{tabular}{l|l}
\hline Veri tabanı & ULAKBİM, YÖK Dokümantasyon \\
\hline Seçilen yayın türleri & Derleme makale, Araştırma makalesi, Yüksek lisans ve Doktora tezleri \\
\hline Arama kelimeleri & $\begin{array}{l}\text { Kaynaştırma eğitimi, okul öncesi eğitim, anne-baba görüşleri, öğretmen görüşleri, } \\
\text { ögretmen adaylarının görüşleri, kaynaştırma eğitimine dahil edilen çocuk görüşleri }\end{array}$ \\
\hline
\end{tabular}

Elde edilen çalışmalara ait analiz ve bulgular, okul öncesi eğitimdeki paydaşlar (Öğretmen ve öğretmen adayları, anne-baba, kaynaştırma eğitimine dahil edilen çocuklar) temel alınarak yapılmıştır. İlgili çalışmalar kapsamında alanyazın taraması yapılırken, "kaynaştırma eğitimi, okul öncesi eğitim, anne-baba görüşleri, öğretmen görüşleri, öğretmen adaylanının görüşleri, kaynaştırma eğitimine dahil edilen çocukların görüşleri” kelimeleri farklı kombinasyonlarla bir araya getirilerek yıl sıralamasına göre taranmıştır. Bu kapsamda öğretmen ve öğretmen adaylarıyla yapıla 21 çalışma, anne ve babalarla yapılan 10 çalışma ve kaynaştırma eğitimine dahil edilen çocuklarla yapılan beş çalışmaya ulaşılmış ve ulaşılan tüm bu çalışmalar analize dahil edilmiştir.

\section{BULGULAR}

Elde edilen çalışmalara ait bulgular; (1) okul öncesi dönemde kaynaştırmaya ilişkin öğretmen ve öğretmen adaylarının görüşleri ile ilgili çalışmalar, (2) okul öncesi dönemde kaynaştırmaya ilişkin anne-baba görüşleri ile ilgili çalışmalar, (3) okul öncesi dönemde kaynaştırmaya ilişkin çocukların görüşleri ile ilgili çalışmalar olarak 3 ana başlık altında sunulmuştur.

\section{Okul Öncesi Dönemde Kaynaştırmaya İlişkin Öğretmen ve Öğretmen Adaylarının Görüşleri İle İlgili Çalışmalar}

Okul öncesi dönemde kaynaştırma eğitimine ilişkin öğretmenlerle yapılmış ve onların görüşlerini ele alan toplamda 21 araştırmaya ulaşılmışır. Yapılan çalışmalara ait çalışma yılı, yazar, çalışmanın ad1, araştırma yöntemi ve çalışma sonucu gibi bilgiler Tablo 2'de sunulmuştur. 
Tablo 2. Okul öncesinde kaynaştırmaya ilişkin öğretmen ve öğretmen adaylarının görüşleri ile ilgili çalışmalar

\begin{tabular}{|c|c|c|c|c|}
\hline $\begin{array}{l}\text { Çalışma } \\
\text { Yilı }\end{array}$ & Araştırmacı & Çalışmanın Adı & Yöntemi & Sonucu \\
\hline 2000 & Temel, Z., F. & $\begin{array}{l}\text { Okul Öncesi Eğitimcilerinin Engellilerin } \\
\text { Kaynaştırılmasına İlişkin Görüşleri }\end{array}$ & $\begin{array}{l}\text {-Nicel araştırma } \\
\text { Araştırmacı tarafindan hazırlanan } \\
\text { anket } \\
\text {-118 öğretmen }\end{array}$ & $\begin{array}{l}\text { Araştırma sonucunda kaynaştırma eğitimiyle ilgili özel eğitim } \\
\text { dersi alan ve almayan öğretmenler arasında istatiksel olarak } \\
\text { anlamlı bir fark bulunamamıstır. }\end{array}$ \\
\hline 2002 & $\begin{array}{l}\text { Sargin, N. ve } \\
\text { Sünbül, A., M. }\end{array}$ & $\begin{array}{l}\text { Okul Öncesi Dönemde Kaynaştırma } \\
\text { Ĕgitimine İlişkin Ö̆ğretmen Tutumları: } \\
\text { Konya İli Örneği }\end{array}$ & $\begin{array}{l}\text {-Nicel araştırma (Survey yöntemi) } \\
\text { - Entegrasyona karşı tutum ölçeği } \\
\text {-Araştırmacılar tarafindan geliştirilen } \\
\text { anket }\end{array}$ & $\begin{array}{l}\text { Araştırma sonucunda katılımcıların genel olarak kaynaştırma } \\
\text { eğitimine yönelik olumlu tutum içinde oldukları fakat } \\
\text { öğretmenlerin engel türlerine ve diğer değişkenlere göre } \\
\text { engellilere yönelik tutumlarının farklılaştı̆̆1 saptanmıştır. }\end{array}$ \\
\hline 2002 & $\begin{array}{l}\text { Varlier, G. ve } \\
\text { Vuran, S. }\end{array}$ & $\begin{array}{l}\text { Okul Öncesi Eğitimi Öğretmenlerinin } \\
\text { Kaynaştırmaya İlişkin Görüşleri }\end{array}$ & $\begin{array}{l}\text { - Nitel araştırma (durum çalışması) } \\
\text {-Yarı yapılandırılmış görüşmeler } \\
\text {-30 öğretmen }\end{array}$ & $\begin{array}{l}\text { Araştırma bulgularına göre çalş̧maya dahil edilen } \\
\text { öğretmenlerin tamamı özel gereksinimli çocukların okul öncesi } \\
\text { eğitim alması gerektiğini savunmuş, ancak ögretmenler, } \\
\text { kaynaştırma eğitimi konusunda kendilerini yetersiz } \\
\text { hissettiklerini dile getirmişlerdir. }\end{array}$ \\
\hline 2004 & $\begin{array}{l}\text { Gözün, Ö. ve } \\
\text { Yikmış, A. }\end{array}$ & $\begin{array}{l}\text { Öğretmen Adaylarının Kaynaştırma } \\
\text { Konusunda Bilgilendirilmelerinin } \\
\text { Kaynaştırmaya Yönelik Tutumlarının } \\
\text { Değişimindeki Etkililiği }\end{array}$ & $\begin{array}{l}\text { - Deneysel çalışma } \\
\text {-Kaynaştırmaya İlişkin Görüşler } \\
\text { Ölçeği } \\
\text { - Bilgi Formu } \\
\text {-174 öğretmen adayı }\end{array}$ & $\begin{array}{l}\text { Araştırmanın bulguları kaynaştırmaya yönelik olarak öğretmen } \\
\text { adaylarının tutumlarının değiştirilmesinde uygulanan } \\
\text { bilgilendirme programının etkili olduğunu göstermektedir. }\end{array}$ \\
\hline 2004 & $\begin{array}{l}\text { Batu, S., } \\
\text { Kırcaali-İftar, } \\
\text { G. ve Uzuner, } \\
\text { Y. }\end{array}$ & $\begin{array}{l}\text { Özel Gereksinimli Öğrencilerin } \\
\text { Kaynaştırıldığı Bir Kız Meslek } \\
\text { Lisesindeki Öğretmenlerin } \\
\text { Kaynaştırmaya İlişkin Görüş ve } \\
\text { Önerileri }\end{array}$ & $\begin{array}{l}\text {-Nitel araştırma } \\
\text { - Görüşmeye dayalı tümevarım } \\
\text { analizi modeli } \\
-19 \text { öğretmen }\end{array}$ & $\begin{array}{l}\text { Araştırma sonucunda gerekli eğitsel kaynaklar, destek özel } \\
\text { eğitim hizmetleri ve donanım sağlandığında Türkiye’de } \\
\text { kaynaştırmanın çok daha başarılı bir biçimde } \\
\text { gerçekleştirilebileceği düşünülebilir. }\end{array}$ \\
\hline
\end{tabular}



Odluyurt, S.

\section{Okul öncesi dönemde gelişimsel}

yetersizlik gösteren çocuklar için gerekli

kaynastırmaya hazırlık becerilerinin ve

bu becerilerden bazılarının etkinlikler

içine gömülen eşzamanlı ipucuyla

öğretiminin etkilerinin belirlenmesi
-Nicel araştırma (Tarama Modeli)

-Okulöncesi Dönemde Gelișimsel

Yetersizlik Gösteren Öğrencilerin

Sahip Olması Gereken

Kaynaştırmaya Hazırlık Becerilerine

Yönelik Görüș Belirleme Anketi
Çalışmanın bulguları, okulöncesi öğretmenlerinin sınıflarında gelişimsel yetersizlik gösteren çocukların bulunması, gelişimsel yetersizlik gösteren çocuklara kaynaștırmaya hazırlık

becerilerinin öğretilmesi ve kendilerine bilgilendirme çalışması yapılması konularında olumlu görüş belirttiklerini göstermiştir.
Odluyurt, S. ve Okul Öncesi Dönemdeki

Batu, E., S.

Kaynastırmaya Hazırlık Becerilerinin

Öğretmen Görüşlerine ve Alanyazın

Taramasına Dayalı Olarak Belirlenmesi

Özen, A.,

Kavnaștırma Öğrencisi Olan

Ergenekon, Y., $\quad$ Okulöncesi Öğretmenlerinin

Kürkçüoğlu, Sinıflarında Yaptıkları Öğretim

B., Ü. ve Genç, Uygulamalarının Belirlenmesi

$\mathrm{D}$

Altun, T. ve

Gülben, A.

Okul Öncesinde Özel Gereksinim

Duyan Çocukların Eğitimindeki

Uygulamalar Ve Karşılaşılan Sorunların

Öğretmen Görüșleri Açısından

Değerlendirilmesi

Gök, G.

Okul öncesi eğitimi öğretmenlerinin

kaynaştırma eğitimine ilişkin görüşleri ve önerileri.
-Nicel araștırma

Okulöncesi Dönemde Gelisimsel

Yetersizlik Gösteren Öğrencilerin

Sahip Olmas1 Gereken

Kaynastırmava Hazırlık Becerilerine

Yönelik Görüş Belirleme Anket

-48 öğretmen

-Nitel araştırma

-Yarı yapılandırılmış görüşme

-Tümevarim analizi

-10 öğretmen

- Nitel Araştırma

-10 okul öncesi öğretmeni

-Yarı yapılandırılmış gözlem formu

-Nitel Araștırma

-10 okul öncesi öğretmeni

- Yarı yapılandırılmış görüşme

Araștırmanın bulguları, öğretmenlerin görüșlerine dayanılarak belirlenen kaynastırmaya hazırlık becerileri alanyazında yer alan becerilerle tutarlilık göstermektedir.

Bulgular, öğretmenlerin öğretim sunarken amaçları oyunun, rutinlerin ve geçişlerin kullanıldığı doğal öğretim gerçeklestirdiklerini, ancak bu uvgulamaların özel gereksinimli öğrencileriyle işe yarayabilmesi için daha sistemli uygulamalara yer verilmesi gerektiğini göstermektedir.

Araștırma sonucunda öğretmenlerin çoğunluğunun özel eğitimle ilgili yeterli bilgiye sahip olmadıkları ve özel gereksinimli çocukların eğitimini desteklemek yönünden yetersiz hissettikleri ile ilgili bulgulara ulașılmıstır

Araștırma bulgularına göre öğretmenler kaynaștırma eğitimi ile ilgili çok az bilgi sahibi olduklarını, bu bilgilerin onlar için yetersiz olduğunu ve kaynaştırma eğitimi ile ilgili yeterli bilgi sahibi olmamalarının sınıflarındaki kaynaștırma uygulamasında yetersiz kalmalarına ve sorunlar yaşamalarına neden olduğunu belirtmişlerdir.

Calıșma sonucunda, öğretmen adaylarının kaynaștırma eğitimini uygun buldukları ve hem özel gereksinimli hem de tipik çocuk açısından iyi bir eğitim olacağını düşündükleri,

- Nicel arastırma (Tarama Modeli) öncesi öğretmeni adaylarının kaynaştırmaya ilişkin görüşlerine etkisi
Kaynastırmaya İlisskin Görüsle

Ölçeği


Doğru, S.Y. ve

Çiftçi, S.

2010

Şahbaz, Ü., ve

Kalay, G.

Okul öncesi Eğitimi Öğretmen

Adaylarının Kaynaştırmaya İlişkin

Görüsslerinin Belirlenmesi
Nicel araştırma (Tarama Modeli) -265 okul öncesi öğretmen adayı -Kaynaştırmaya İlişkin Görüşler Ölçeği

- Nitel verilere dayalı durum

çalışması

-Görüsmeci Bilgi Formu

- Görüşme Soru Formu

-9 öğretmen

Okul Öncesi Öğretmenlerinin Engelli Öğrencilerin Kaynaștırılmasına Yönelik Bilgilendirilmelerinin Kaynaştırmaya İlişkin Görüşlerinin Değişmesindeki Etkililiği

\section{Sucuoğlu, B. Okul Öncesi Öğretmenlerinin}

Bakkaloğlu, H. Kaynaștırmaya İlișkin Bilgi Düzeyleri

Karasu, F.

Demir, Ş. ve

Akalın, S.

Bozarslan, B

ve Batu, S.
-Deneysel Çalışma

- Öntest-sontest kontrol grubu

-Kaynaștırma Hakkında

Düşüncelerim Ölçeği

-60 öğretmen

- Nicel araştırma (Tarama Modeli)

-169 okul öncesi öğretmeni

-Kaynaştırma Bilgi Testi (KBT) ancak öğretmen açısından güç ve yorucu olduğunu

düşündükleri anlașilmıștır.

Araştırma bulguları, okulöncesi öğretmen adaylarının kaynaştırmaya ilişkin görüşlerinin özel eğitim dersi alıp almamalarına göre farklılașıp farklılaşmadığı açısından incelendiğinde, özel eğitim dersi alan öğretmen adayları, almayanlara göre daha olumlu görüşe sahip gibi görünmektedir.

Araştırma sonucunda okul öncesi eğitimi öğretmenlerinin, Kaynaştırma Ĕ̈itimi Hizmet Içi Eğitim Programlarının uygulamada yaşadıkları sorunlara yönelik olarak düzenlenmesine ve yanı sıra özel eğitim danışmanlı̆̆ı, sınıfta yardımcı bir öğretmen ve kaynak oda desteğine ihtiyaç duydukları tespit edilmiștir.

Araştırma sonucunda, araştırmaya katılan okulöncesi öğretmenlerinin engellilerin kaynastırılmasına ilișkin görüşlerinin olumlu olduğu ve görüşleri arasında anlamlı bir fark olmadığı bulunmuştur.

Araştırma sonucunda okul öncesi öğretmenlerinin kaynaştırma uygulamaları konusundaki bilgi düzeylerinin oldukça düșük olduğunu göstermiştir. Ayrıca, öğretmenlerin bilgilerinin deneyimlerine ve sınıflarında özel gereksinimli çocuk olmasına bağlı olarak değișmediği, ancak lisans eğitiminde özel eğitime giriș dersi alan öğretmenlerin bilgilerinin daha fazla olduğu belirlenmiștir.

Arastırma sonucunda elde edilen bulgularda, anaokullarında çalışan eğiticiler özel gereksinimli çocuklarla ilgili yeterli bilgiye sahip olmadıklarını ifade etmişlerdir. Özellikle, kaynaştırma eğitimine sıcak bakmayan öğretmenler, her firsatta konuyla ilgili bilgiye ihtiyaçları olduğunu belirtmişlerdir.

Araștırma sonucunda kaynaștırma uygulamalarında çeșitli sorunlar yaşandığı ve bu sorunlara ebeveynler, öğrenciler, yöneticiler, öğretmenler ve eğitim ortamlarının kaynaklık ettiğ
Ana Sınıflarında Kaynaştırma Eğitim Uygulamalarına İlişkin Öğretmen-
-Nitel araştırma

Yarı Yapılandırılmış Görüşme Formlar1 
Rehber Öğretmen ve Ebeveyn

Görüşleri

Kale, M.,

Dikici

Okul Öncesi Öğretmenlerinin

Kaynastırma Eğitimi Uygulamaların

Sigirtmaç,

Nur, l. ve

Abbak, B.S.

Gezer, M., S.

lişkin Görüşlerinin İncelenmesi

Bulunan Okul Öncesi Öğretmenlerin

Kaynaştırma Eğitimine Yönelik rol

Algilarının Belirlenmesi

Hazırlanmasına İliş̧kin Görüşler

Gürgür, H. ve

Hasanoğlu-

Türkiye'de Kaynaștırma Eğitimine

Yönelik Öğretmenlerin Görüșlerine

Yazçayır, G.
-Nitel araştırma

-Yarı Yapılandırılmıs Bireysel

Görüşme

Nitel araștırma

-Betimsel analiz tekniğ

- Yarı yapılandırılmış görüşme

formu

-19 öğretmen

-Nitel araştırma

-Yarı yapılandırılmış görüşme formu

-8 ögrretmen

görülmüştür. Sorunların çözümüne yönelik öğretmenlerin

toplantılar, bireysel görüşmeler ve sınıf içi etkinlikler

düzenlediği, rehber öğretmenlerin ise seminerler, oryantasyon

çalışmaları ve ikna yollarına başvurdukları belirlenmiştir.

Araștırma sonucunda, öğretmenler sınıfların fiziki alanının yeni programdaki öğrenme merkezlerini düzenlemek için yeterli olmadığını, kaynaştırma eğitimi öncesinde herhangi bir hazırlık yapmadıklarını ve bireyselleștirilmiș eğitim planı hazırlamakta kendilerini yetersiz bulduklarını belirtmişlerdir.

Araștırma bulgularına göre öğretmenler BEP hazırlama ve uygulama, özel gereksinimli öğrencinin sosyal gelissimini destekleme, özel gereksinimli öğrenci ile ilgili sınıftaki diğer çocukları ve ailelerini bilgilendirme ve özel gereksinimli bireyin ailesine biloi aktarımında bulunma görevlerini kendi sorumlulukları olarak görmektedir.

Öğretmenlerin çoğu yazılı ve sistematik olarak BEP hazırlamadıklarını, ailelerin ise sürece katılımının düșük olduğunu ifade etmişlerdir. Ayrıca öğretmenler, BEP hazırlanması ve uygulanması ile ilgili kullanıcı dostu yazılı kaynaklara ihtiyaç duyduklarını ifade etmişlerdir.

- Nitel arastırma

- Meta-Etnografik Bir Calıșma
Incelenen araștırmalarda öğretmenlerin kaynaştırma eğitiminin özel gereksinimli öŏrencilere yararlarından bahsederken sadece öğrencilerin sosyal becerilerinin gelişimine katkı sağladığı yönündeki ifadeleri dikkat çekmektedir.

Tezlerinin Sentezlenmesi: 
Tablo 2' de öğretmenlerin kaynaştırma eğitimine ilişkin görüşlerinin yer aldığ̣ araştırmalar tabloya eklenmiştir. Ulaşılan ilk araştırmada özel eğitim dersi alan ve almayan öğretmenler karşılaştırnlarak; öğretmenler kaynaştırma eğitimi konusunda bilgi eksikliğine sahip olduklarını dile getirmişlerdir (Temel, 2000). Çalışmaların bulgularına göre (Sargın-Sünbül, 2002; Varlıer ve Vuran, 2002; AltınGülben, 2009; Gök, 2009; Kılıç, 2011) öğretmenlerin kaynaştırmaya ilişkin olumlu tutum içinde oldukları fakat kaynaştırmaya dahil edilen çocukların özellikleri ve öğretmenlerin kendilerini kaynaştırma konusunda yetersiz hissetmeleri kaynaştırma eğitiminde sorunların ortaya çıkmasına zemin oluşturmuştur. Öğretmenlerin yetersizliklerin giderilmesine yönelik çözüm önerileri sunduğu araştırmalarda (Batu, Kırcaali-İftar ve Uzuner, 2004; Odluyurt, 2007; Özaydın ve Çolak, 2011; Koçyiğit, 2015) hizmet içi eğitimler, bilgilendirme çalışmalar ya da rehber öğretmen aracıllı̆̆ ile hem öğretmenlere hem de velilere yapılacak olan toplantı ve seminerlerin kaynaştırma eğitimini olumlu etkileyeceği belirtilmiştir. Aynı zamanda birden fazla kaynaştırma öğrencisine sahip sınıflarda yardımcı öğretmen ihtiyacı da geliştirilen çözüm önerileri arasındadır. Öğretmen adaylarına yönelik yapılan araştırmalarda (Gözün ve Yıkmış, 2004; Şahbaz ve Kalay, 2010) kaynaştırma ve özel eğitim amacıyla verilen eğitimlerin öğretmen adaylarının olumlu tutum sergilemesinde etkili olduğu gözlemlenmiştir. Kayılı, Koçyiğit, Doğru ve Çiftçi ise (2010) öğretmen adaylarının kaynaştırma eğitimi dersi sonucunda kaynaştırma eğitimini gerekli buldukları fakat öğretmen açısından yorucu ve güç olarak nitelendirdikleri sonucuna varılmıştır. Sınıfında kaynaştırma öğrencisi olan ya da kaynaştırma uygulaması içinde yer alan öğretmenlerle yapılan araştırmalarda ise; Özen (2008) sınıf içerisinde özel gereksinimli öğrenciye uygulama yaparken öğretmenlerin daha çok oyun yolunu kullandıkları ve doğal öğretimler gerçekleştirdikleri sonucuna ulaşmıştır. Gezer (2017) sınıfinda kaynaştırma öğrencisi olan öğretmenlerin; özel gereksinimli çocuk için BEP uygulanması, ailesinin bilgilendirilmesi ve özel gereksinimli çocuğun tipik gelişim gösteren çocuklarla sosyal uyum göstermesini öğretmenlerin kendilerine ilişkin rol alg1ları içerisinde belirtmişlerdir. Kale, Dikici Sığırtmaç, Nur, Abbak (2016)'ın, öğretmenlerin kaynaştırma eğitimi için görüşlerini belirttikleri çalışmasında; öğretmenlerin kaynaştırma eğitimi açısından sınıfları elverişli bulmadıkları, bireyselleştirilmiş eğitim programı hazırlama konusunda kendilerini yetersiz hissettikleri ve MEB 2013 programında etkinlik planları içerisinde yer alan uyarlama kısmıyla ilgili yeterince bilgi sahibi olmadıkları sonucuna varılmıştır. Tekin-Ersan ve Ata (2017) öğretmenlerin bireyselleştirilmiş eğitim programı hazırlama ve uygulama konusunda sistematik olarak bir program hazırlamadıklarını fakat bu konuda yardımcı yazılı kaynaklara ihtiyaç duyduklarını belirtmişlerdir. Özel anaokullarında çalışan öğretmenlerle yapılan araştırmada (Bozarslan ve Batu, 2014) öğretmenlerin kaynaştırma eğitimine sıcak bakmayarak kaynaştırma hakkında yeterli bilgiye sahip olmadıkları saptanmıştır.

\section{Okul Öncesi Dönemde Kaynaştırmaya İlişkin Anne-Baba Görüşleri İle İlgili Çalışmalar}

Erken Çocukluk Çalışmaları Dergisi Cilt $5 \cdot$ Say1 $2 \cdot$ Ekim 
Okul öncesi dönemde kaynaştırma eğitimine ilişkin anne-babalarla yapılmış ve anne-babaların görüşlerini inceleyen toplamda 10 çalışmaya ulaşılmıştır. İlgili çalışmalara ait; çalışma yılı, yazar, çalışmanın adı, araştırma yöntemi ve çalışma sonucu gibi bilgiler Tablo 3'te sunulmuştur. 
Tablo 3. Okul öncesinde kaynaştırmaya ilişkin anne-baba görüşleri ile ilgili çalışmalar

\begin{tabular}{|c|c|c|c|c|}
\hline $\begin{array}{l}\text { Çalışma } \\
\text { Y1lı }\end{array}$ & Araştırmacı & Çalışmanın Adı & Yöntemi & Sonucu \\
\hline 2005 & Konuk, R. & $\begin{array}{l}\text { Anaokulu ve Anasınıfina Devam } \\
\text { Eden Normal ve Entegre } \\
\text { Eğitimi Alan Çocukların } \\
\text { Ebeveynlerinin Okul Öncesi } \\
\text { Eğitim Kurumu Seçimlerini } \\
\text { Etkileyen Etmenler }\end{array}$ & $\begin{array}{l}\text { - Nicel araştırma (tarama modeli) } \\
\text {-194 ebeveyn } \\
\text {-Kişisel bilgi formları } \\
\text {-Anne-babaların okul öncesi kurum } \\
\text { seçimlerini etkileyen etmenleri belirleme } \\
\text { anketi }\end{array}$ & $\begin{array}{l}\text { Araştırma bulgularına göre, kaynaştırmanın uygulandığı okul } \\
\text { öncesi kurumlara devam eden çocukların ailelerinin görüşleri, } \\
\text { engelli çocuğu bulunan ailelerin görüşlerine göre anlamlı bir } \\
\text { farklıllık içermektedir. }\end{array}$ \\
\hline 2013 & Bakkaloğlu, H. & $\begin{array}{l}\text { Ebeveynlerin Gözüyle Özel } \\
\text { Gereksinimli Çocukların Erken } \\
\text { Müdahaleden Okul Öncesi } \\
\text { Programlara Geçiş Süreci }\end{array}$ & $\begin{array}{l}\text { - Nitel araştırma (Betimsel yöntem) } \\
\text { - Yarı yapılandırılmış görüşme } \\
\text {-1 baba, } 7 \text { anne }\end{array}$ & $\begin{array}{l}\text { Araştırma sonucunda, ebeveynlerin geçiş öncesinde en çok } \\
\text { uygun kurum bulamama kaygısı, geçiş sonrasında ise kuruma } \\
\text { ilişkin güvensizlik yaşadıkları ve çocuklarının yeni } \\
\text { ortama/gruba uyum sağlayamaması ve akranları tarafindan } \\
\text { reddedilmesi sorunuyla karşılaştıkları bulunmuştur. }\end{array}$ \\
\hline 2013 & $\begin{array}{l}\text { Tuş, Ö. ve Çiftci } \\
\text { Tekinarslan, İ. }\end{array}$ & $\begin{array}{l}\text { Okul Öncesi Kaynaştırma } \\
\text { Eğitimine Devam Eden Özel } \\
\text { Gereksinimli Çocukların } \\
\text { Karşılaştıkları Güçlüklerin } \\
\text { Annelerin görüşlerine Göre } \\
\text { Belirlenmesi }\end{array}$ & $\begin{array}{l}\text { - Nitel araştırma } \\
\text {-Görüşmeye dayalı tümevarım analizi } \\
\text {-Yarı yapılandırılmış görüşme } \\
\text {-9 anne }\end{array}$ & $\begin{array}{l}\text { Araştırmada aile ve çocuğun okul öncesi eğitimde okul } \\
\text { yöneticilerinin olumsuz tutumlarıyla karşılaştı̆̆ı görülmüştür. } \\
\text { Okul öncesi kaynaştırma ortamında özel gereksinimli } \\
\text { öğrencilerin grup faaliyetlerine katılmada güçlük yaşadıkları } \\
\text { belirlenmiştir. }\end{array}$ \\
\hline 2014 & Duran, S. & $\begin{array}{l}\text { Zihinsel Engelli Bireylerin } \\
\text { Ebeveynlerine Verilen Psiko- } \\
\text { eğitimin Öznel İyi Oluş ve Öz } \\
\text { Duyarllğa Etkisinin } \\
\text { Değerlendirmesi }\end{array}$ & $\begin{array}{l}\text {-Nicel araştırma } \\
\text { - 2x4'lük split-plot faktöryel (karışık) } \\
\text { desen } \\
\text {-Kişisel Bilgi Formu } \\
\text {-Öznel İyi Oluş Ölçeği } \\
\text {-Öz duyarlık Ölçeği } \\
\text {-Maslach Tükenmişlik Ölçeği } \\
\text {-420 ebeveyn }\end{array}$ & $\begin{array}{l}\text { Psiko-eğitimin zihinsel engelli bireylerin ebeveynlerin öznel iyi } \\
\text { oluş ve öz duyarlı̆̆a etkisini saptamak amacıyla yapılan bu } \\
\text { çalışmada, deney grubundaki ebeveynlerin, psiko-eğitimden bir } \\
\text { ay ve üç ay sonrası dönemde öznel iyi oluş ölçeği puan } \\
\text { ortalamasında anlamlı düzeyde artma olduğu belirlenmiştir. }\end{array}$ \\
\hline 2014 & $\begin{array}{l}\text { Piştav-Akmeşe, } \\
\text { P. ve Kayhan, } \\
\text { N. }\end{array}$ & $\begin{array}{l}\text { Okul Öncesi ve İlkokula Devam } \\
\text { Eden Özel Gereksinimli } \\
\text { Öğrencilerin Aile Katılım } \\
\text { Düzeylerinin İncelenmesi }\end{array}$ & $\begin{array}{l}\text { - Nicel araştırma (tarama modeli) } \\
\text { - Kişisel Bilgi Formu } \\
\text { - Aile Katılım Ölçeği } \\
\text {-50 çocuk ve anneleri }\end{array}$ & $\begin{array}{l}\text { Araştırma sonucunda çocuğa ilişskin değişkenlerden cinsiyet, } \\
\text { aileye ait değişkenlerden ise anne eğitim düzeyi ile aileye ait } \\
\text { gelir düzeyinin aile katılım puanlarında bir farklıı̆ığa neden } \\
\text { olmadığı öte yandan çocukların devam ettiği eğitim düzeyi ile } \\
\text { annelerin çalışma durumunun aile katılım düzeyinde anlamlı bir } \\
\text { farklılık oluşturduğu belirlenmiştir. }\end{array}$ \\
\hline
\end{tabular}




\begin{tabular}{|c|c|c|c|c|}
\hline 2015 & $\begin{array}{l}\text { Kaytez, N., } \\
\text { Durualp, E. ve } \\
\text { Kadan, G., }\end{array}$ & $\begin{array}{l}\text { Engelli Çocuğu Olan Ailelerin } \\
\text { Gereksinimlerinin ve Stres } \\
\text { Düzeylerinin İncelenmesi }\end{array}$ & $\begin{array}{l}\text { - Nicel araştırma (Tarama modeli) } \\
\text {-200 ebeveyn } \\
\text { - Nicel araştırma } \\
\text { - Genel Bilgi Formu } \\
\text {-Aile Gereksinimlerini Belirleme Aracı } \\
\text {-Aile Stresini Değerlendirme Ölçeği }\end{array}$ & $\begin{array}{l}\text { Araştırma sonucunda; annelerin, ilkokul mezunlarının ve } \\
\text { çalışmayanların aile gereksinimlerinin fazla olduğu, ilkokul } \\
\text { mezunlarının, dört-altı çocuğu olanların, çocuğuna doğumdan } \\
\text { sonra üç yıl içinde engel tanısı konulanların stres düzeylerinin } \\
\text { yüksek olduğu saptanmıştır. }\end{array}$ \\
\hline 2017 & $\begin{array}{l}\text { Avşaroğlu, S. ve } \\
\text { Gilik, A. }\end{array}$ & $\begin{array}{l}\text { Özel Gereksinimli Çocuğa Sahip } \\
\text { Anne-Babaların Kayg1 } \\
\text { Durumlarına Göre Umutsuzluk } \\
\text { Düzeylerinin İncelenmesi }\end{array}$ & $\begin{array}{l}\text { - Nicel araştırma (Tarama modeli) } \\
\text {-351 anne-baba } \\
\text { - Kişisel Bilgi Formu } \\
\text { - Durumluk-Sürekli Kayg1 Envanteri } \\
\text { - Beck Umutsuzluk Ölçeği }\end{array}$ & $\begin{array}{l}\text { Araştırma sonucunda, katılan ailelerin gelecekle ilgili duygular, } \\
\text { beklentiler ve umutsuzluk puan ortalamalarının, yaş } \\
\text { değişkenine göre anlamlı düzeyde farklılaşmadığı, motivasyon } \\
\text { kaybı puan ortalamalarının ise anlamlı düzeyde farklılaştı̆̆ } \\
\text { görülmüştür. Herhangi bir işte çalışan ailelerin durumluk kayg1 } \\
\text { puan ortalamaları, çalışmayanlara göre anlamlı düzeyde yüksek } \\
\text { bulunmuştur. }\end{array}$ \\
\hline 2017 & $\begin{array}{l}\text { Çetrez İşcan, G. } \\
\text { ve Malkoç, A. }\end{array}$ & $\begin{array}{l}\text { Özel Gereksinimli Çocuğa Sahip } \\
\text { Ailelerin Umut Düzeylerinin } \\
\text { Başa Çıkma Yeterliği ve } \\
\text { Yılmazlık Açısından İncelenmesi }\end{array}$ & $\begin{array}{l}\text { - Nicel araştırma (tarama modeli) } \\
\text { - } 71 \text { anne ve } 70 \text { baba } \\
\text { - Aile Yılmazlık Ölçeği (AYÖ) } \\
\text { - Başa Çıkma Yeterliği (BÇY) } \\
\text { - Sürekli Umut Ölçeği } \\
\text { - Kişisel Bilgi Formu }\end{array}$ & $\begin{array}{l}\text { Araştırma sonucunda ailelerin yılmazlık ve başa çıkma } \\
\text { yeterliklerinin umut düzeylerini anlamlı düzeyde açıkladığı } \\
\text { bulunmuştur. }\end{array}$ \\
\hline 2018 & $\begin{array}{l}\text { Ersoy Quadır, S. } \\
\text { ve Temiz, G. }\end{array}$ & $\begin{array}{l}\text { Engelli Çocuğu Olan Annelerin } \\
\text { Gereksinimlerini Etkileyen } \\
\text { Faktörlerin İncelenmesi }\end{array}$ & $\begin{array}{l}\text { - Nicel araştırma (Tarama Modeli) } \\
\text {-122 anne } \\
\text { - Aile Gereksinimlerini Belirleme Aracı }\end{array}$ & $\begin{array}{l}\text { Araştırma sonucunda engelli çocuğu olan annelerin } \\
\text { gereksinimleri eğitim düzeyleriyle, aile gelirleriyle, sahip } \\
\text { oldukları çocuk sayısılya, devletten ekonomik destek almalarıla } \\
\text { ve çocuk bakımında akrabalarından bireysel yardım almalarılyla } \\
\text { ilişkili bulunmuştur. }\end{array}$ \\
\hline 2019 & $\begin{array}{l}\text { Karakuş, Ö. ve } \\
\text { Kırlıoğlu, M. }\end{array}$ & $\begin{array}{l}\text { Engelli Bir Çocuğa Sahip } \\
\text { Olmanın Getirdiği Yaşam } \\
\text { Deneyimleri: Anneler Üzerinden } \\
\text { Nitel Araştırma }\end{array}$ & $\begin{array}{l}\text {-Nitel araştırma } \\
\text {-Yarı yapılandırılmış görüşme formu } \\
-14 \text { anne }\end{array}$ & $\begin{array}{l}\text { Araştırma sonucunda engelli bireye sahip anneler, çocuklarının } \\
\text { bakımı konusunda aile büyüklerinden sosyal destek aldıklarını } \\
\text { ancak toplumsal destek görmediklerini, bunun sebebi olarak } \\
\text { toplumun engellilik konusunda yeterince bilinçli olmadıklarını } \\
\text { belirtmişlerdir. }\end{array}$ \\
\hline
\end{tabular}


Tablo 3'te okul öncesinde kaynaştırmaya ilişkin anne-baba görüşleri ile ilgili çalışmalara yer verilmiştir. Kaynaştırma sürecinin başlangıcında ilk ve en önemli adım okul seçimidir. Okul seçimi konusunda ebeveynlerle yapılan araştırmada (Konuk, 2005) özel gereksinimli çocuğa sahip ailelerin okul seçerken ilk olarak sağlıklı ve güvenli olmasına ve eğitimin kalitesiyle birlikte eğitim verilen ortama dikkat ettikleri görülmektedir. Yine okul seçerken ailelerin anaokulundan beklentilerinde ilk sırada sosyal davranışların öğrenilmesi yer almaktadır. Bakkaloğlu (2013) ailelerin bakış açısından, özel gereksinimli çocukların erken müdahaleden okul öncesi eğitime geçiş sürecine dair yaptı̆̆1 çalışamada; ailelere geçiş konusunda yeterince hizmet sunulmadığı, geçiş sürecinde zorlandıkları ve geçişten sonraki süreçte çocuklarının arkadaşları tarafından reddedilmesi konusunda kaygı yaşadıklanı sonucuna varmıştır. Okul öncesi dönemde kaynaştırma öğrencileri; öz bakım becerilerinde, sınıfa uyumda, gün içinde yapılan faaliyetlerde ve oyunlara katılmada yaşanılan güçlükler gibi birçok sorunla karşılaşmaktadırlar (Tuş ve Çiftci-Tekinarslan, 2013).

Özel gereksinimli çocuğa sahip ailelerin gereksinimleri en çoktan en aza doğru; bilgi gereksinimi, çevreye açılama gereksinimi, maddi gereksinim ve genel destek ve toplumsal hizmet gereksinimidir (Ersoy Quadır ve Temiz, 2018). Duran (2014), zihin olarak yetersiz çocuğun ailesine yaşadıkları sorunlarla başa çıkma konusunda verilen psiko-eğitimin yararlarını konu alan çalışmasında verilen eğitimin ailelerin kayg1 ve korku düzeylerinde azalmaya ve stresle başa çıkmada olumlu tutum sergilemelerine sebep olduğunu ortaya koymuştur. Kaytez ve arkadaşlarının (2005) engelli çocuğa sahip olan ailelerin stres düzeylerini ve gereksinimlerini inceledikleri çalışmada; eğitim durumunun stres düzeyi üzerinde etkili olduğu kanısına varmışlardır. Eğitim durumunun yanı sıra ailelerin kayg1 ve stres düzeyini etkileyen diğer bir faktör olan bir işte çalışma/çalışmama durumunun ailelere etkisi incelendiğinde (Avşaroğlu ve Gilik, 2017) herhangi bir işte çalışan ailelerin kayg1 düzeyleri, çalışmayan ailelere göre daha yüksek bulunmuştur. Yine bu araştırmaya göre, ailelerin gelecekle ilgili duygular, beklentiler ve umutsuzluk düzeylerinin, yaşa göre farklılaşmadığı ancak motivasyon kaybının anlamlı düzeyde farklılaştığı bulunmuştur. Çetrez İşcan ve Malkoç (2017) ise ailelerin başa çıkma stratejileri ve umut düzeyleri arasındaki ilişkiyi incelediklerinde etkili başa çıkma stratejisi kullanan ailelerin umut düzeylerinin yüksek olduğu kanısına varmışlardır.

Özel gereksinimli çocuğa sahip ailelerin katılım durumuna bakıldığında (Piştav Akmeşe ve Kayhan, 2014) anneye ait eğitim düzeyi ile aile gelir düzeyinin ailelerin katılım düzeyinde farklılaşmaya sebep olmadığ1 fakat çocukların eğitim düzeyi ile annelerin çalışma durumu arasında aile katılımında anlamlı bir farklılık oluştuğu belirlenmiştir. Çocuklarının devam ettiği eğitim seviyesi ilkokul düzeyinde olan annelerin aile katılım düzeyleri daha yüksek iken çocuklarının devam ettiği eğitim düzeyi okul öncesi olan annelerin aile katılım düzeyleri daha düşüktür. 


\section{Okul Öncesi Dönemde Kaynaştırmaya İlişkin Çocukların Görüşleri İle İlgili Çalışmalar}

Okul öncesi dönemde kaynaştırma eğitimine ilişkin çocuklarla yapılmış ve onların görüşlerini inceleyen toplamda beş çalışmaya ulaşılmıştır. İlgili çalışmalara ait; çalışma yılı, yazar, çalışmanın adı, araştırma yöntemi ve çalışma sonucu gibi bilgiler Tablo 4'te sunulmuştur. 
Tablo 4. Okul öncesinde kaynaştırmaya ilişkin çocukların görüşleri ile ilgili çalışmalar

\begin{tabular}{|c|c|c|c|c|}
\hline $\begin{array}{l}\text { Çalışma } \\
\text { Y111 }\end{array}$ & Araştırmacı & Çalışmanın Adı & Yöntemi & Sonucu \\
\hline 2007 & Aykara, A. & $\begin{array}{l}\text { Kaynaştırma Eğitimi Sürecindeki } \\
\text { Bedensel Engelli Ö̆ğrencilerin } \\
\text { Sosyal Uyumlarını Etkileyen } \\
\text { Etmenler ve Okul Sosyal } \\
\text { Hizmeti }\end{array}$ & $\begin{array}{l}\text { - Nicel araştırma (tarama modeli) } \\
\text {-Görüşme formu } \\
\text { - Sosyal Uyum Envanteri } \\
\text { - Çok Boyutlu Algılanan Sosyal Destek } \\
\text { Ölçeği } \\
\text {-70 öğrenci }\end{array}$ & $\begin{array}{l}\text { Araştırma bulgularına göre, öğrenciler ve aileleri, genel } \\
\text { olarak alt ve orta sosyoekonomik düzeye sahiptirler. } \\
\text { Neredeyse tamamının engeli, doğum sonrası } \\
\text { nedenlerden kaynaklanmaktadır. Öğrencilerin sosyal } \\
\text { yaşamlarında en çok karşılaştıkları güçlükler, duygusal } \\
\text { sorunlar ve fiziksel çevre koşullarının yetersizliğine ilişkin } \\
\text { sorunlardır. }\end{array}$ \\
\hline 2009 & $\begin{array}{l}\text { Çulhaoğlu } \\
\text { İmrak, H. ve } \\
\text { Sığırtmaç, A. }\end{array}$ & $\begin{array}{l}\text { Kaynaştırma Uygulanan } \\
\text { Okulöncesi Sınıflarında Akran } \\
\text { İlişkilerinin İncelenmesi }\end{array}$ & $\begin{array}{l}\text {-Nitel araştırma } \\
\text { - Yapilandirılmamış gözlem } \\
-80 \text { çocuk }\end{array}$ & $\begin{array}{l}\text { Araştırma sonucunda tipik gelişim gösteren çocuklar } \\
\text { kaynaştırma çocuklarını oyunlarına dahil etmişlerdir. } \\
\text { Kaynaştırma eğitimine karşı olan öğretmenlerin } \\
\text { sinıflarında daha sorunlu akran ilişkileri olduğu } \\
\text { saptanmıştır. }\end{array}$ \\
\hline 2009 & Güleryüz, Ş., O. & $\begin{array}{l}\text { Kaynaştırma Eğitimine Devam } \\
\text { Eden Engelli Öğrencilerin } \\
\text { Akranları ile İlişkilerinde } \\
\text { Karşılaştıkları Sorunların } \\
\text { Değerlendirilmesi }\end{array}$ & $\begin{array}{l}\text {-Nitel araştırma } \\
\text {-Yarı yapılandırılmış görüşme formu } \\
-27 \text { öğrenci }\end{array}$ & $\begin{array}{l}\text { Araştırma sonucunda kaynaştırma eğitimi alan } \\
\text { çocukların diğer arkadaşları tarafından eksik ve yetersiz } \\
\text { algılandıkları için şiddete ve dışlanmaya maruz kaldıkları } \\
\text { bulunmuştur. }\end{array}$ \\
\hline 2010 & Orhan, M. & $\begin{array}{l}\text { Okul Öncesi Kaynaştırma } \\
\text { Öğrencileri ile Normal Gelişim } \\
\text { Gösteren Öğrencilerin Sosyal } \\
\text { Beceri ve Problem } \\
\text { Davranıslarının Düzeyi ile } \\
\text { Öğretmenlerin Kaynaştırmaya } \\
\text { İlişkin Görüşlerinin İncelenmesi }\end{array}$ & $\begin{array}{l}\text { - Nicel araştırma (tarama modeli) } \\
\text {-Kişisel Bilgi Formu } \\
\text {-Okulöncesi ve Anasınıfı Davranış } \\
\text { Ölçekleri } \\
\text {-Kaynaştırmaya İlişkin Görüşler Ölçeği } \\
\text {-57 öğretmen, } 64 \text { kaynaştırma öğrencisi, } \\
320 \text { tipik gelişim gösteren öğrenci }\end{array}$ & $\begin{array}{l}\text { Araştırma bulguları tipik gelişim gösteren çocuklar ile } \\
\text { kaynaştırmaya dahil edilen çocuklar arasında sosyal } \\
\text { beceri açısından anlamlı bir farklılık bulmuştur. Olumsuz } \\
\text { kaynaştırma tutumuna sahip öğretmen sınıflarında bu } \\
\text { fark daha belirgindir. }\end{array}$ \\
\hline 2015 & $\begin{array}{l}\text { Olçay Gül, S. ve } \\
\text { Vuran, S. }\end{array}$ & $\begin{array}{l}\text { Normal Sınıflara Devam Eden } \\
\text { Özel Gereksinimli Öğrencilerin } \\
\text { Kaynaştırma Uygulamasına } \\
\text { İlişkin Görüşleri ve Karşılaştıkları } \\
\text { Sorunlar }\end{array}$ & $\begin{array}{l}\text {-Nitel durum çalışması } \\
\text {-Yar1 yapılandırılmış görüşme } \\
\text {-14 öğrenci }\end{array}$ & $\begin{array}{l}\text { Kaynaştırma eğitimi alan ve öğrenme güçlüğü ve zihin } \\
\text { yetersizliği olan ögrenciler için farklılaşma ve } \\
\text { uyarlamalara yeterince yer verilmediği, sinıflarda uygun } \\
\text { olmayan davranıslara fazla odaklanılıp, cezaya sık sik yer } \\
\text { verildiği saptanmıștır. }\end{array}$ \\
\hline
\end{tabular}


Tablo 4'te okul öncesinde kaynaştırmaya ilişkin çocukların görüşleri ile ilgili çalışmalar tablolaştırılmıştır. Aykara (2007) bedensel olarak yetersiz öğrencilerin sosyal uyumlarını incelediği çalışmasında öğrencilerin sosyal hayatta en çok; duygusal sorunlarla ve fiziksel çevrenin yetersizliğiyle karşılaştıklarını saptamıştır. Okul öncesi sınıflarında yer alan kaynaştırma öğrencilerinin diğer arkadaşları tarafindan oyunlara dahil edildiği fakat olumsuz öğretmen tutumu hakim olan sınıflarda akran ilişkilerinin de olumsuz olduğu gözlemlenmiştir (Çulhaoğlu-İmrak ve Sığırtmaç, 2009). Fakat Güleryüz’ün (2009) yaptığı araştırmada kaynaştırma eğitimi alan çocukların diğer arkadaşları tarafından eksik ve yetersiz algılandıkları için şiddete ve dışlanmaya maruz kaldığ1 sonucu ortaya çıkmıştır. Orhan ise (2010) öğretmenlerin kaynaştırmaya ilişkin görüşlerini incelediği çalışmasında özel gereksinimli çocuklar ile tipik gelişim gösteren çocuklar arasında sosyal beceri bağlamında farklılıklar olduğuna ulaşmıştır. Öte yandan kaynaştırma eğitimine ilişkin olumsuz tutum içerisinde olan öğretmenlerin sınıflarında bu farkın daha belirgin olduğunu gözlemlemiştir. Olçay-Gül ve Vuran (2015) kaynaştırmaya dahil edilen çocuklar için uyarlamalara yeterince yer verilmediği ve aynı zamanda kaynaştırma eğitiminin uygulandığı sınıflarda cezaya sık sık yer verildiğini gözlemlemiştir.

\section{TARTIŞMA VE SONUÇ}

Türkiye'de okul öncesinde kaynaştırma eğitimine ilişkin paydaş görüşlerinin tematik dağılımlarını ortaya koyan bu araştırmada kaynaştırmaya ilişkin öğretmen görüşleri, anne-baba görüşleri ve kaynaştırmaya dahil edilen çocukların görüşleri incelenmiştir.

Mevcut çalışmada öğretmenlerle yapılmış çalışmalara ait tarama sonucu, sınıfinda kaynaştırma öğrencisi olan veya daha önce herhangi bir kaynaştırma öğrencisiyle çalışan öğretmenlerin kaynaştırma eğitimine karşı kendilerini eksik ve yetersiz hissettiklerini ortaya koymuştur (Odluyurt, 2007; Altun ve Gülben, 2009; Gök, 2009; Sucuoğlu ve ark., 2014). Çoğunluğu lisans eğitiminde özel eğitim ya da kaynaştırma eğitimi almış olmasına rağmen bu derslerin yeterli olmadığını; hizmet içi eğitimler, konferanslar ve seminerler gibi bilgilendirici çalışmalarla desteklenmek istediklerini ifade etmişlerdir. Kaynaştırma eğitimi için sınıfların uygun olmadığı da öğretmenler tarafindan dile getirilmiştir. Özel anaokullarında çalışan öğretmenler kaynaştırma eğitimine sıcak bakmadıklarını söylemişlerdir. Sınıfında kaynaştırma öğrencisi olan öğretmenlerin BEP hazırlamaya dair bilgi düzeylerinin oldukça eksik olduğu saptanmıştır. Öğretmenlerin çoğu hiç BEP hazırlamadıklarını dile getirmişlerdir. Aynı zamanda, 2013 Okul Öncesi Eğitim Programı’ nda yer alan uyarlama kısmı da öğretmenler tarafından ya bilinmemekte ya da uygulanmamaktadır. Diğer taraftan, öğretmen adaylarına verilen kaynaştırma eğitimi dersinin adayların olumlu tutum sergilemesinde yardımcı 
olduğu gözlenmiştir fakat dersi almayan adaylar kaynaştırma eğitimini öğretmen için güç ve yorucu bulduklarını ifade etmişlerdir.

Kaynaştırma eğitiminin ayrılmaz bir parçası da ailedir çünkü bu sürecin başarılı bir şekilde yürütebilmesi onların katılımı ile gerçekleşmektedir ve onlara duyulan ihtiyaç göz ardı edilemez (Lessard, 2015). Bu nedenle özel gereksinimli çocuğa sahip ailelerin yaşadığı zorluklar; okul seçimi, çocuğun sosyal uyumunda yaşanan zorluklar, öğretmen seçimi, çocuğun diğer akranları tarafından kabul görmeme endişesi olarak sıralanabilir. Aileler çocuklarının erken müdahaleden sonra kaynaştırma eğitimine geçiş aşaması hakkında yeterince bilgi sunulmadığı için zorlandıklarını ifade etmektedirler. Bu nedenle çoğu çocuklarının okula uyumu ve akranları tarafından kabulü hakkında kayg1 yaşamaktadırlar. Kaytez ve arkadaşlarının (2005) ailelerin kaygı düzeylerini yönetmeleri için verdikleri psiko-eğitimler olumlu sonuçlar vermiştir. Bu da ailelerin bilgi eksikliği yaşadığını ve bilgilendirme çalışmalarının olumlu sonuçlar verdiğini gösterebilir. Aile katılımında annenin herhangi bir işte çalışmasının etkili olduğu söylenebilir. Çalışan annelerin kaygı durumlarının çalışmayan annelerden yüksek olduğu gözlemlenmiştir (Avşaroğlu ve Gilik, 2017).

Kaynaştırma eğitiminin en önemli paydaşı olan çocuklarla yapılan araştırmalarda Çulhaoğlu-İmrak ve Sığırtmaç (2009) tipik gelişim gösteren çocukların oyunlarında ve sınıf ortamında özel gereksinimli arkadaşlarını da dahil ettiği gözlemlenmiştir fakat Güleryüz’ün (2009) yaptığ1 araştırmada özel gereksinimli çocuklar tipik gelişim gösteren arkadaşları tarafından eksik ve yetersiz algılandıklanı için şiddete ve dışlanmaya maruz kalmışır. Aynı sınıfta eğitim gören tipik gelişim gösteren çocuklarla kaynaştırma öğrencilerinin sosyal uyum bağlamında anlamlı derecede farkları olduğuna ulaşılmıştır. Sinıflarda müfredatta yer alan uyarlama kısmı yeterince ve amacına uygun uygulanmamaktadir.

Sonuç olarak, toplumsal algının yanı sıra, öğretmenler bilgi yetersizliklerinden dolayı kaynaştırma eğitimine ve özel gereksinimli çocuklara karşı olumsuz tutum içerisinde olabilmektedirler (Lessard, 2015). Benzer şekilde, öğretmenlerin kaynaştırma eğitimi uygulamalarına karşı olan olumsuz yaklaşımları, inanç eksiklikleri, özel gereksinimli çocuklar için genel eğitim ortamında yeterli olmayacağını ve çocuklara katkı sağlamayacağını düşünmeleri de kaynaştırma uygulamalarının başarılı olmasındaki engellerden birisi olarak gösterilmektedir (Küçük-Doğaroğlu ve BapoğluDümenci, 2015). Bu sebeple, üniversitelerin öğretmen yetiştirme programlarında verilen özel eğitim derslerinin, gerçek okul deneyimi ile bütünleştirilmesi yararlı olacaktır. Diğer taraftan bu konuda sunulan hizmet içi eğitimlerin yetersiz kaldığını belirten öğretmenler için bulundukları şehirlerde sürekli olarak danışabilecekleri özel eğitim rehberlik kurumlarının açılması ve yardım almaları sağlanabilir. Bununla birlikte ailenin, çocuklarının durumunu topluma ve çevreye 
açıklamak zorunda hissetmesi ve bu durumda zorlanması, özel gereksinimli çocuklarının özellikleri ile ilgili yeterli bilgiye sahip olmamaları, onların yaşadıkları en büyük sorunlardan bir tanesidir. Bu sebeple ailelere de danışma ve rehberlik sağlayacak kurumların sayısını arttırmak ve çocuklarındaki gereksinime özel olarak bilgi ve destek sunmak yararlı olabilecektir.

\section{KAYNAKÇA}

Alper, S. \& Ryndak, D., L. (1992). Educating students with severe handicaps in regular classes. The Elementary School Journal, 92(3), 373-387.

Altun, T. ve Gülben, A. (2009). Okul öncesinde özel gereksinim duyan çocukların eğitimindeki uygulamalar ve karşılaşılan sorunların öğretmen görüşleri açısından değerlendirilmesi. Selçk. Üniversitesi Abmet Keleşoğlu Eğitim Fakültesi Dergisi, 28, 253-272.

Avşaroğlu, S. ve Gilik, A. (2017). Özel gereksinimli çocuğa sahip anne-babaların kaygı durumlarına göre umutsuzluk düzeylerinin incelenmesi. İlkögretim Online, 16(3), 1022-1035.

Aydoğdu, Ö. G. F., Akalın, A., Polat, B., İrice, N., \& Akpınar, M. (2016). Okul öncesi öğretmenlerin özel gereksinimli çocukların tanılanması konusundaki görüşlerinin incelenmesi. Manas Sosyal Arașttrmalar Dergisi, 5(4), 13- 21.

Aykara, A. (2007). Kaynaştırma eğitimi sürecindeki bedensel engelli öğrencilerin sosyal uyumlarını etkileyen etmenler ve okul sosyal hizmeti. Toplum ve Sosyal Hizmet, 22(1), 63-84

Bakkaloğlu, H. (2013). Ebeveynlerin gözüyle özel gereksinimli çocukların erken müdahaleden okul öncesi programlara geçiş süreci. Ankara Üniversitesi Eğitim ve Bilim, 38(169), 311-327

Bapoğlu-Dümenci, S., Gürsoy. F. ve Aral, N. (2016). Türkiye'de okul öncesi dönemdeki üstün potansiyelli ve üstün zekâlı olan çocukların eğitimleri. Kastamonu Ĕ̈itim Dergisi, 24(5), 24692480 .

Batu, S. (2000). Kaynaştırma, destek hizmetler ve kaynaştırmaya hazırlık etkinlikleri. Öz̧el Eğitim Dergisi, 2 (4), 35-45.

Batu, S., Kırcaali-İftar, G. ve Uzuner, Y. (2004). Özel gereksinimli öğrencilerin kaynaştırıldığı bir kız meslek lisesindeki öğretmenlerin kaynaştırmaya ilişkin görüş ve önerileri. Ankara Üniversitesi Eğitim Bilimleri Fakültesi Özel Eğitim Dergisi, 5(2), 33-50

Berry, R. A. W. (2006). Creating a better classroom environment for students with learning disabilities. Learning Disability Quarterly, 32(3), 123-141.

Booth, T. and Ainscow, M (2002) Index for inclusion: Developing learning and participation in schools. Centre for Studies on Inclusive Education, United Kingdom.

Bozarslan, B. ve Batu, S. (2014). Özel anaokullarında çalışan eğiticilerin okulöncesi dönemde kaynaştırma ile ilgili görüş ve önerileri. Abant İzzet Baysal Üniversitesi Eğitim Fakültesi Dergisi, 14(2), 86-108. 
Büyüköztürk, Ş., Kılıç Çakmak, E., Akgün, Ö.E., Karadeniz, Ş. ve Demirel, F. (2014). Bilimsel arastırma yöntemleri (17. Baskı). Ankara: Pegem Yayınları

Çetrez İşcan, G. ve Malkoç, A. (2017). Özel Gereksinimli çocuğa sahip ailelerin umut düzeylerinin başa çıkma yeterliği ve yılmazlık açısından incelenmesi. Trakya Üniversitesi Eğitim Fakültesi Dergisi, 7(1), 120-127.

Çulhaoğlu-İmrak, H. ve Sı̆̆ırtmaç, A. (2009). Kaynaştırma uygulanan okulöncesi sınıflarında akran ilişkilerinin incelenmesi. International Journal of Early Childhood Special Education, 3(1), 38-65.

Doğan, M., Gürgür, H., Girgin, Ü., Karasu, H. P. ve Turan, Z. (2016). Tanıdan eğitime Kosova Cumhuriyetinde işitme engelli çocuklara yönelik düzenlemelerin incelenmesi. Turkish Online Journal of Qualitative Inquiry, 7(2), 31-70.

Duran, S. (2014). Zibinsel engelli bireylerin ebeveynlerine verilen psikoeğitimin öznel iyi oluş ve öz duyarlğga etkisinin değerlendirmesi (Yayımlanmamış Doktora Tezi). Marmara Üniversitesi, İstanbul.

Eripek, S. (2003). Okulöncesi dönemde özel eğitim. Anadolu Üniversitesi Açı Öğretim Fakültesi Yaymi, 756, 1-14.

Ersoy Quadır, S. ve Temiz, G. (2018). Engelli çocuğu olan annelerin gereksinimlerini etkileyen faktörlerin incelenmesi. Uluslararası Sosyal Arasttrmalar Dergisi, 11(61), 831-839.

Gezer, M. S. (2017). Sinffinda kaynastırma ögrencisi bulunan okul öncesi ögretmenlerinin kaynaștırma ĕgitimine yönelik rol algularmm belirlenmesi (Yayımlanmamış Yüksek Lisans Tezi). Eskişehir Anadolu Üniversitesi, Eskişehir.

Gök, G. ve Erbaş, D. (2009). Okul öncesi eğitimi öğretmenlerinin kaynaştırma eğitimine ilişkin görüssleri ve önerileri. International Journal of Early Childhood Special Education, 3(1), 66-87.

Gözün, Ö. ve Yıkmış, A. (2004). Öğretmen adaylarının kaynaştırma konusunda bilgilendirilmelerinin kaynaştırmaya yönelik tutumlarının değişimindeki etkililiği. Ankara Üniversitesi Ë̆̈itim Bilimleri Fakültesi Örel Ë̆̈itim Dergisi, 5(2), 65-77.

Graham, S. ve Perrin, D. (2007). What we know, what we still need to know: Teaching adolescents to write. Scientific Studies in Reading, 11(4), 313-336.

Güleryüz, Ş. O. (2009). Kaynaşttrma eüitimine devam eden engelli ögrencilerin akranlar ile iliskillerinde karşılaştıklar sorunları değerlendirilmesi (Yayımlanmamış Yüksek Lisans Tezi). Selçuk Üniversitesi, Konya.

Gürgür, H. ve Hasanoğlu Yazçayır, G. (2019). Türkiye'de kaynaştırma eğitimine yönelik öğretmenlerin görüşlerine odaklanılmış lisansüstü eğitim tezlerinin sentezlenmesi: MetaEtnografik Bir Çalışma. Eğitimde Nitel Araştırmalar Dergisi, 7(2), 845-872.

Hornby, G. (2015). Inclusive special education: Development of a new theory for the education of children with special educational needs and disabilities. British Journal of Special Education, 42(3), 234-256.

İlgar, Ş. (2017). Öğretmen adaylarının özel gereksinimli öğrencilerle ilgili farkındalığının incelenmesi. Hasan Ali Yücel Ë̆itim Fakültesi Dergisi, 313-338. 
Jacobs, P. \& Fu, D. (2014). Students with learning disabilities in an inclusive writing classroom. Journal of. Language and Literacy Education [Online], 10(1), 100-113.

Kale, M., Dikici Sığırtmaç, A., Nur, İ. ve Abbak, B.S. (2016). Okul öncesi öğretmenlerinin kaynaştırma eğitimi uygulamalarına ilişkin görüşlerinin incelenmesi. Uluslararası Erken Cocukluk Eğitimi Çalşsmalar Dergisi, 1(2), 35-45.

Karakuş, Ö. ve Kırlığlu, M. (2019). Engelli bir çocuğa sahip olmanın getirdiği yaşam deneyimleri: anneler üzerinden nitel araştırma. Selçuk Üniversitesi Sosyal Bilimler Enstitüsü Dergisi, 41, 96112.

Kayılı, G., Koçyiğit, S., Doğru, S.Y. ve Çiftçi, S. (2010). Kaynaştırma eğitimi dersinin okul öncesi öğretmeni adaylarının kaynaştırmaya ilişkin görüşlerine etkisi. Mehmet Akif Ersoy Üniversitesi Eğitim Fakültesi Dergisi, 20, 48-65.

Kaytez, N., Durualp, E. ve Kadan, G., (2015). Engelli çocuğu olan ailelerin gereksinimlerinin ve stres düzeylerinin incelenmesi. Ë̆̈tim ve Öğretim Araştırmalar Dergisi, 4(1), 197-214.

Kulıç, A. F. (2011). Okul öncesi ögretmenlerinin engelli ögrencilerin kaynaştırlmasma yönelik bilgilendirilmelerinin kaynastırmaya ilișkin görüslerinin değissmesindeki etkililï̆i (Yayımlanmamış Yüksek Lisans Tezi). Mehmet Akif Ersoy Üniversitesi, Burdur.

Koçyiğit, S. (2015). Ana sınıflarında kaynaştırma eğitimi uygulamalarına ilişkin öğretmen-rehber öğretmen ve ebeveyn görüssleri. Uluslararası Türkşe Edebiyat Kültür Eğitim Dergisi, 4(1), 391 415.

Konuk, R. (2005). Anaokulu ve anasinfina devam eden normal ve entegre eğitimi alan çocuklarn ebeveynlerinin okul öncesi eğitim kurumu seçimlerini etkileyen etmenler (Yayımlanmamış Yüksek Lisans Tezi). Selçuk Üniversitesi, Konya.

Küçük-Doğaroğlu, T. ve Bapoğlu-Dümenci, S., S. (2015). Sinıflarında kaynaştırma öğrencisi bulunan okul öncesi öğretmenlerin kaynaştırma eğitimi ve erken müdahale hakkındaki görüşlerinin incelenmesi. Hacettepe Üniversitesi Sağhlk Bilimleri Fakülttesi Dergisi, Uluslararası Katılimlı III. Çocuk Gelişimi ve Eğitimi Kongresi "Erken Müdahale”, 1(2), 460-473

Lessard, S. A. (2015). Parents of students with disabilities views of schools' efforts to facilitate their involvement in their child's educational progress. Senior Honors Projects, 39.

MEB. (2018). Özel Eğitim Hiẓmetleri Yönetmeliği.

Odluyurt, S. (2007). Okul öncesi dönemde gelisimsel yetersiə̧lik gösteren çocuklar için gerekli kaynaştırmaya hąurllk becerilerinin ve bu becerilerden bazlarmm etkinlikler içine gömülen eşzamanl ipucuyla ögretiminin etkilerinin belirlenmesi (Yayımlanmamış Doktora Tezi). Anadolu Üniversitesi, Eskişehir.

Odluyurt, S. ve Batu, E., S. (2008). Okul öncesi dönemdeki kaynaştırmaya hazırlık becerilerinin öğretmen görüşlerine ve alanyazın taramasına dayalı olarak belirlenmesi. Kuram ve Uygulamada Ë̆itim Bilimleri / Educational Sciences: Theory \& Practice, 9(4), 1819-1851. 
Olçay-Gül, S. ve Vuran, S. (2015). Normal sinıflara devam eden özel gereksinimli öğrencilerin kaynaştırma uygulamasına ilişkin görüşleri ve karşılaştıkları sorunlar. Eğitim ve Bilim, 40(180), 169-195.

Orhan, M. (2010). Okul öncesi kaynaştırma öğrencileri ile normal gelisim gösteren ögrrencilerin sosyal beceri ve problem davranıslarmm dïzeyi ile ögretmenlerin kaynaştrmaya iliskkin görüslerinin incelenmesi (Yayımlanmamış Yüksek Lisans Tezi). Eskişehir Anadolu Üniversitesi, Eskişehir.

Özaydın, L. ve Çolak, A. (2011). Okul öncesi öğretmenlerinin kaynaştırma eğitimine ve okul öncesi eğitimde kaynaştırma eğitimi hizmet içi eğitim programına ilişkin görüşleri. Kalem Eğitim ve Insan Bilimleri Dergisi 2011, 1(1), 189 - 226.

Özen, A., Ergenekon, Y., Kürkçüoğlu, B., Ü. ve Genç, D. (2008). Kaynaştırma öğrencisi olan okulöncesi öğretmenlerinin sınıflarında yaptıkları öğretim uygulamalarının belirlenmesi. Eskişehir Anadolu Üniversitesi Sosyal Bilimler Dergisi, 13(2), 153-166.

Piştav Akmeşe, P. ve Kayhan, N. (2014). Okul Öncesi ve İlkokula Devam Eden Özel Gereksinimli Öğrencilerin Aile Katılım Düzeylerinin İncelenmesi. Cukurova University Faculty of Education Journal, 43(2), 39-56.

Sarg1n, N. ve Sünbül, A. M. (2002). Okul öncesi dönemde kaynaştırma eğitimine ilişkin öğretmen tutumlar1: Konya ili örneği. XI. Eğitim Bilimleri Kongresi. Yakın Doğu Üniversitesi, Lefkosa, KKTC.

Sönmez, N. ve Biçak, B. (2017). An adaptation of the Turkish Version of the teacher efficacy for the inclusion of young children with disabilities scale. International Online Journal of Educational Sciences, 9(1), $156-173$.

Sucuoğlu, B., Bakkaloğlu, H., Karasu, F., Demir, Ş. ve Akalın, S. (2014). Okul Öncesi Öğretmenlerinin Kaynaştırmaya İlişkin Bilgi Düzeyleri. Kuram ve Uygulamada Ĕgitim Bilimleri Educational Sciences: Theory \& Practice, 14(4), 1467-1485

Şahbaz, Ü. (1997). Öğretmenlerin özürlü çocuklarn kaynaştırlması konusunda bilgilendirilmelerinin

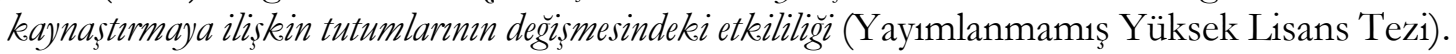
Abant İzzet Baysal Üniversitesi, Bolu.

Şahbaz, Ü. ve Kalay, G. (2010). Okul öncesi eğitimi öğretmen adaylarının kaynaştırmaya ilişkin görüşlerinin belirlenmesi. Mehmet Akif Ersoy Üniversitesi Eğitim Fakültesi Dergisi, 19, 116-135.

Tekin-Ersan, D. ve Ata, S. (2017). Okul öncesi öğretmenlerinin bireyselleştirilmiş eğitim program1 hazırlanmasına ilişkin görüssleri. Trakya Üniversitesi Eğitim Fakültesi Dergisi XV. Uluslararası Katılimlı Simı Öğretmenliği Eğitimi Sempozyumu USOS, Özel Sayısı, 162-177.

Temel, Z., F. (2000). Okul öncesi eğitimcilerinin engellilerin kaynaştırılmasına ilişkin görüşleri. Hacettepe Üniversitesi Ë̈itim Fakültesi Dergisi, 18, 148-155.

Tuş, Ö. ve Çifci-Tekinarslan, İ. (2013). Okul öncesi kaynaştırma eğitimine devam eden özel gereksinimli çocukların karşılaştıkları güçlüklerin annelerin görüşlerine göre belirlenmesi. Dumlupinar Üniversitesi Sosyal Bilimler Dergisi, 35, 151-165.

UNICEF. (2004). Insan Haklarn Evrensel Bildirgesi. 
Uzun, G. (2009). Kaynaştırma uygulamalarnda ilkögretim müdürlerinin rolü ve kaynaşttrma uygulamalarna ilişkein görü̈s ve önerileri (Yayımlanmamış Yüksek Lisans Tezi). Marmara Üniversitesi, İstanbul.

Varlıer, G. ve Vuran, S. (2002). Okul öncesi eğitimi öğretmenlerinin kaynaştırmaya ilişkin görüşleri. Kuram ve Uygulamada Ë̆itim, 6(2), 553-585.

Yazıcıoğlu, T. (2018). Kaynaştırma uygulamalarının tarihsel süreci ve Türkiye'de uygulanan kaynaştırma modelleri. Nevssehir Hacı Bektas Veli Üniversitesi SBE Dergisi, 8(1), 92-110. 